\title{
Fundamentals of Psychological and Pedagogical Diagnostics of Children with Autism Spectrum Disorders
}

\section{Основи психолого-педагогічної діагностики дітей із розладами спектра аутизму}

Kateryna Ostrovska

Dr. in Psychology, Professor
Катерина Островська доктор психологічних наук, професор

E-mail: katerynaostrova@gmail.com

ORCID: http://orcid.org/0000-0002-5891-2542

Researcher ID: T-1550-2018

Ihor Ostrovskyi

Dr. in Technical Sciences, Professor
Ігор Островський доктор технічних наук, професор

E-mail: ihor.p.ostrovskyi@lpnu.ua ORCID: http://orcid.org/0000-0001-7867-7132 Researcher ID: Q-9754-2017

Viktoriia Loboda

Ph.D. in Pedagogy, Assistant Professor
Вікторія Лобода кандидат педагогічних наук, доцент

E-mail: vita.loboda@gmail.com

ID ORCID: https://orcid.org/0000-0001-6091-4232

Researcher ID: D-9687-2018

Ivan Franko National

University of Lviv, Ukraine

1, Universytetska street, Lviv,

Ukraine, 79000
Львівський національний університет ілені Івана Франка, Украӥна вул. Університетська, 1, м. Львів, Україна, 79000 
Original manuscript received June 14, 2018

Revised manuscript accepted October 21, 2018

\section{ABSTRACT}

The article presents the complex of psychodiagnostic methods for determining the degree of autism and social competences of children with autism spectrum disorders (ASD). Diagnostic methods are determined to use for primary and in-depth diagnostics of ASD children as the basis for the development of educational and developmental programs in the inclusive space: M-CHAT, screening diagnostic method SCQ - for screening children aged 1,5-3 years and definition of the risk group of the autistic spectrum; CARS, CASD, ADI-R techniques - to determine the main characteristics of ASD children; Bine-Simon's techniques, LEITER-3, and O.R. Luria method - to determine the level of mental development; PEP-R method - to determine the psycho-educational profile of ASD children. The validity criteria of the LEITER-3 and Binet-Simon method for determining the level of intelligence in autistic children were checked and recommended to use for diagnostics of ASD children. The stage of analysis and interpretation of the results is the development of an individual development program: an analysis of the results of the survey by each method. To analyze the quantitative results of the study the mathematical and statistical methods of processing using the software package STATISTICA-8.0 were applied: comparative analysis according to Student t-criterion, factor, cluster and correlation analyzes; holistic interpretation of results; creation of the profile of the child's development and compilation of psychological characteristics; statement of psychological diagnosis; determination of the direction of correctional and pedagogical and educational work; implementation of the child's development forecast; development of an individual program of correction of development; defining directions for working with parents; joint decision-making by parents and specialists on the further route of the child.

The complex of diagnostic methods that allow to optimize the diagnostics of children with ASD was revealed: M-CHAT, screening diagnostic method SCQ - for carrying out screening of children aged 1,5-3 years and determination of the risk group of the autistic spectrum; CARS, CASD, ADI-R techniques - to determine the main characteristics of children with RSA, LEITER-3, $O$. $R$. Luria - to determine the level of mental development; PEP-R methodology - to determine the psycho-educational profile of children with ASD.

The comparative analysis of foreign and domestic diagnostic methods for implementation of psychological and pedagogical diagnostics of children with 
ASD; In particular, the validity criteria of the LEITER-3 for determining the level of intelligence in autistic children were checked.

The final step is to present the results of the survey to parents of the child, providing recommendations for future work with the child, discuss and agree short and long-term goals and the definition of further education and rehabilitation route of the child, and also for implementing individual program development.

Key words: diagnosis, competence, children, autism spectrum disorders, inclusive education.

\section{Вступ}

На сьогоднішній день у європейській практиці освіти дітей з особливими потребами, зокрема дітей із розладами спектра аутизму (РСА), переважає тенденція до інклюзивного навчання (Gavalda, 2012: 4072). Однак, за свідченням учителів, які мають досвід роботи з дітьми з PCA, їх інклюзивне навчання в загальноосвітній школі (Lindsay, 2013: 348) є викликом для сучасної школи з огляду на необхідність створення спеціальних умов (структурування приміщення, часу, дидактичних матеріалів і самих занять) та урахування особливостей дітей аутистичного спектра (обмежені соціальні навички, стереотипна поведінка, порушення у сфері комунікації та уяви) (Eldar, 2010: 98). У практиці української інклюзивної школи створення спеціальних умов для навчання дітей з особливими потребами, зокрема з РСА, відбувається за рахунок додаткового фінансування навчальних закладів. Вирішення питання урахування специфічних особливостей дітей із PCA можливе на шляху впровадження ефективної психолого-педагогічної діагностики показників розвитку дитини, яка здійснюватиметься в інформаційних ресурсних центрах інклюзивної освіти та в самих навчальних закладах.

Мета статті - провести апробацію комплексу психодіагностичних методик для визначення ступеня аутизму та соціальних компетентностей дітей зі спектром аутистичних порушень. 


\section{Завдання статті}

Надання рекомендацій щодо вибору діагностичних методик дослідження дітей із різним ступенем аутизму, апробація методичного інструментарію для визначення рівня інтелектуального розвитку в немовних дітей із РСA.

\section{Методи та методики дослідження}

Вимоги до медичної діагностики дітей із РСА в Україні сформульовані у роботі (Martsenkovsky, 2011: 145). Зокрема, серед методик, зазначених у клінічному протоколі, рекомендовані модифікований скринінговий тест аутизму (MCHAT) для виявлення ознак аутизму в ранньому віці, шкала спостереження для діагностики аутизму (ADOS-2), інтерв'ю для діагностики аутизму (ADI-R), а також методики CASD (опитувальник розладів аутистичного спектра) та CARS (шкала оцінювання дитячого аутизму). Методичні засади проведення психолого-педагогічної діагностики дітей із РСА викладені у роботах (Островська, 2012: 146). Основні підходи до оцінки рівня інтелектуального розвитку дітей із РСА представлені у праці (Шульженко, 2009: 87). Стандарти проведення психолого-педагогічної діагностики сформульовані у роботі (Скрипник, 2013: 38). Зокрема, автор виокремлює необхідність проведення ранньої (за методиками CHAT, M-CHAT, ADI-R для виявлення групи ризику), диференційної (за методиками CARS i ADOS для виокремлення ознак аутистичного спектра) та поглибленої (за методиками PEP-R (психоосвітній профіль), VABS (шкала адаптивної поведінки Вайнленда) та ін.) діагностики як підгрунтя розроблення навчальних і розвивальних програм для дитини. Основною проблемою застосування цих методик в інклюзивному навчальному просторі є відсутність адаптації вищевказаних методик в українських реаліях і, відповідно, слабка обізнаність фахівців (ПМК, IРЦ, психологів навчальних закладів) щодо можливості їх використання в практичній роботі. 
Для проведення повної та якісної психолого-педагогічної діагностики дітей із РСА було складено таку послідовність обстеження, що корелює з етапами діагностики у праці (Filipek, 2000: 441):

1. Первинний етап діагностики. Сюди відносимо:

- біографічні дані;

- вивчення документації (медичних записів, епікризів і виписок психоневрологічних установ, наявних психолого-педагогічних характеристик тощо);

- збір інформації зі слів батьків дитини;

- спостереження за дитиною.

Завданнями етапу первинної діагностики є:

- аналіз первинних даних, отриманих на основі вивченої документації, бесіди з батьками і спостереження за дитиною;

- налагодження контакту з батьками для подальшої співпраці;

- налагодження контакту з дитиною для проведення повної та достовірної поглибленої діагностики.

2. Стадія аналізу й інтерпретації результатів - це розробка індивідуальної програми розвитку й аналіз результатів опитування за кожним методом. Для аналізу кількісних результатів застосовано математичні й статистичні методи обробки з використанням програмного пакета STATISTICA-8.0: порівняльний аналіз за ступенем t-критерію, факторний, кластерний і кореляційний аналізи; цілісне тлумачення результатів; створення профілю розвитку дитини та складання психологічних характеристик; виклад психологічної діагностики; визначення напрямку виправно-педагогічної та виховної роботи; реалізація прогнозу розвитку дитини; розробка індивідуальної програми корекції розвитку; визначення напрямків роботи з батьками; спільне прийняття батьками та фахівцями рішень щодо подальшого шляху дитини.

На підставі результатів опитування дослідник розвиває профіль дитини, формує психологічні та педагогічні 
характеристики дитини. Характеристики включають дані про поведінку дитини під час опитування, співпрацю з дослідником, рівень пізнавального розвитку дитини, роботу окремих психічних функцій, якість і ступінь тяжкості порушень, визначається рівень прояву аутичного розладу.

На наступних етапах результати комплексного обстеження дитини обговорюються командою фахівців, створюється індивідуальна програма розвитку дитини, передбачається ефективність використання вибраних методів.

Остаточним кроком є представлення результатів опитування батькам дитини, надання рекомендацій щодо подальшої роботи з дитиною, обговорення та узгодження короткотермінових і довгострокових цілей та визначення подальшого навчання і шляхів реабілітації дитини (Сайко, 2013: 395), а також реалізація окремих програм розвитку.

Колективом авторів розроблено комплекс психодіагностичних методик, який може бути успішно використаний для діагностики аутизму (Ostrovska, 2013: 135). До складу комплексу психодіагностичних методик входять:

- «Шкала оцінювання дитячого аутизму» CARS для визначення рівня аутизму;

- методика «Психолого-освітній профіль покращеної версії» PEP-R, адаптована K. Островською (Островська, 2012: 146), для діагностики дітей з аутизмом;

- шкала тестів для визначення рівня розумового розвитку;

- методика нейропсихологічного дослідження для визначення рівня психофізичного розвитку.

Методика CARS - стандартизований інструментарій для оцінювання порушень аутистичного спектра у дітей віком від двох років - дає змогу діагностувати дітей з аутизмом, відрізняти їх від дітей із вадами розвитку, але без синдрому аутизму. Також шкала дає можливість відрізнити ступінь аутизму від легкого й помірного - до значного.

Методика PEP-R надає інформацію щодо розвитку вміння наслідування, сприйняття, дрібної та великої мото- 
рики, зорово-рухової координації, пізнавальної діяльності, спілкування й активного мовлення. PEP-R також дає змогу визначити ступені розладів поведінки в стосунках між людьми (нав'язування контактів та емоційних реакцій), в іграх, у способі реагування на зовнішні подразники, а також ступінь розладів розвитку мовлення.

Шкала тестів розумового розвитку є стандартизованою методикою, що дозволяє оцінити інтелектуальний розвиток дітей віком від трьох до п'ятнадцяти років. Варто зазначити, що власне результати тестування за методикою (порівняно з іншими методиками, які досліджують рівень розумового розвитку в дітей зі спектром аутистичних порушень) найбільш наближені (з точністю до 1-1,5 місяця) до результатів тестування за методикою PEP-R (це підтверджують і наші дослідження, і дослідження фахівців Українського НДІ соціальної і судової психіатрії та наркології МОЗ України).

Для визначення рівня психофізичного розвитку дитини використовується нейропсихологічна діагностика.

Серед зазначених вище методик іншомовні методики CARS i PEP-R потребували адаптації.

Адаптація україномовних версій CARS (Childhood autism rating scale) «Шкала оцінювання дитячого аутизму» та PEP-R (Psychoeducational Profile-Revised) «Психолого-освітній профіль покращеної версії» проводилася у два етапи. На першому етапі була здійснена процедура їх послідовного перекладу (кілька незалежних прямих і зворотних перекладів, експертиза за участю фахівців у галузі психології, що вільно володіють англійською мовою). У якості експертів, які визначали лінгвістичну валідність методик, виступили викладачі кафедри психології Львівського національного університету імені Івана Франка і практичні психологи, які працюють в установах охорони здоров'я та освіти міста Львова. На другому етапі оцінювалися психометричні показники методик: надійність (у тому числі ретестова), перевірка внутрішньої узгодженості 
субшкал і валідність (у тому числі конструктна і критеріальна); потім була проведена стандартизація.

Загальна кількість досліджуваних, які склали вибірку для адаптації методик, становила 56 осіб (діти віком від 3 до 5 років - 18, діти віком від 6 до 16 років - 38) із м. Львова, м. Полтави, м. Києва та м. Кривого Рогу. Пілотні дослідження проводилися у таких навчальних закладах: ЛСШ «Надія» та ДНЗ № 165 м. Львова, Полтавському навчально-реабілітаційному центрі Полтавської обласної ради, спецшколі-інтернаті № 26 м. Києва та комунальному закладі освіти «Криворізький багатопрофільний навчально-реабілітаційний центр «Натхнення» Дніпропетровської обласної ради» .

\section{Результати та дискусії}

Ретестова надійність методик перевірялася за участю 56 дітей шляхом повторного тестування через чотири тижні. Використовувався коефіцієнт кореляції Пірсона. Внутрішню надійність методик перевірено методом альфа Кронбаха на вибірці з 394 дітей. Результати перевірки ретестової та внутрішньої надійності методик наведено (відповідно) в табл. 1 і табл. 2.

Таблиця 1. Перевірка ретестової та внутрішньої надійності україномовної версії методики «Шкала оцінювання дитячого аутизлу»

\begin{tabular}{|l|c|c|}
\hline \multicolumn{1}{|c|}{ Найменування шкали } & $\begin{array}{c}\text { Значення } \\
\text { коефіціснта } \\
\text { кореляції } \\
\text { Пірсона }\end{array}$ & $\begin{array}{c}\text { Показник } \\
\text { альфа } \\
\text { Кронбаха }(\alpha)\end{array}$ \\
\hline 1 & 2 & 3 \\
\hline Взаємини з людьми & $0,699 * *$ & $0,836 * *$ \\
\hline Імітація & $0,710 * *$ & $0,875 * *$ \\
\hline Емоційна реакція & $0,719 * *$ & $0,901 * *$ \\
\hline Володіння тілом & $0,748 * *$ & $0,845 * *$ \\
\hline
\end{tabular}


Продовження табл. 1

\begin{tabular}{|l|c|c|}
\hline \multicolumn{1}{|c|}{1} & 2 & 3 \\
\hline Використання об'єктів & $0,756 * *$ & $0,821 * *$ \\
\hline Адаптація до змін & $0,819 * *$ & $0,835 * *$ \\
\hline Зорова реакція & $0,700 * *$ & $0,792 * *$ \\
\hline Слухова реакція & $0,697 * *$ & $0,892 * *$ \\
\hline Смак, запах, реакція на дотик & $0,732 * *$ & $0,788 * *$ \\
\hline Боязкість / нервозність & $0,669 * *$ & $0,882 * *$ \\
\hline Вербальна комунікація & $0,781 * *$ & $0,837 * *$ \\
\hline Невербальна комунікація & $0,659 * *$ & $0,931 * *$ \\
\hline Рівень активності & $0,836 * *$ & $0,830 * *$ \\
\hline $\begin{array}{l}\text { Рівень і ступінь інтелектуаль- } \\
\text { ного розвитку }\end{array}$ & $0,771 * *$ & $0,823 * *$ \\
\hline Загальне вражкення & $0,822 * *$ & $0,936 * *$ \\
\hline
\end{tabular}

Примітка: ** $\mathrm{p} \leq 0,01$.

Таблиця 2. Перевірка ретестової та внутрішньої надійності україномовної версії методики «Психолого-освітній профіль»

\begin{tabular}{|c|c|c|}
\hline Найменування шкали & $\begin{array}{c}\text { Значення } \\
\text { коефіцієнта } \\
\text { кореляції } \\
\text { Пірсона }\end{array}$ & $\begin{array}{c}\text { Показник } \\
\text { альфа } \\
\text { Кронбаха ( } \alpha)\end{array}$ \\
\hline Наслідування & $0,702 * *$ & $0,889 * *$ \\
\hline Сприйняття & $0,875 * *$ & $0,814 * *$ \\
\hline Дрібна моторика & $0,786 * *$ & $0,888 * *$ \\
\hline Велика моторика & $0,812 * *$ & $0,903 * *$ \\
\hline Зорово-рухова координація & $0,742 * *$ & $0,902 * *$ \\
\hline Пізнавальна діяльність & $0,808 * *$ & $0,797 * *$ \\
\hline $\begin{array}{l}\text { Спілкування, активне } \\
\text { мовлення }\end{array}$ & $0,789 * *$ & $0,834 * *$ \\
\hline
\end{tabular}

Примітка: ** $\mathrm{p} \leq 0,01$. 
Перевірка валідності. Конструктна валідність визначалася за участі 8 експертів, серед яких були викладачі кафедри психології Львівського національного університету імені Івана Франка та практикуючі психологи Львівської області (7 викладачів та 1 практикуючий психолог). Експерти заповнювали опитувальники за досліджуваного 3 високим і з низьким рівнем аутизму. Відмінності в середніх значеннях виявилися достовірно відмінними на рівні $\mathrm{p}<0,001$, що свідчить про надійність методик за критерієм конструктної валідності.

Для валідизації методик також було використано оцінку критеріальної валідності, що визначалася методом порівняння контрастних груп. У якості критерію виступали відмінності між групами умовно здорових дітей і групами дітей з аутистичними проявами (56 осіб). Достовірність відмінностей визначалася за допомогою t-критерію Стьюдента. Результати порівняльного аналізу засвідчили, що умовно здорові діти мають статистично значущі вищі показники за всіма шкалами методик.

Дискрилінативність. Для визначення дискримінативності завдань використовувався коефіцієнт кореляції кожного завдання із загальним балом методик. Відповідно, коефіцієнт кореляції Пірсона результуючого показника методики «Шкала оцінювання дитячого аутизму» 3 кожним із завдань лежить у межах від $\mathrm{r}=0,486 \%$ до $\mathrm{r}=0,815 * *$, а методики «Психолого-освітній профіль» - у межах від $\mathrm{r}=0,522 * *$ до $\mathrm{r}=0,848 * *$ на рівні високої статистичної значущості $\mathrm{p} \leq 0,01$.

Стандартизація. Розрахунок нормативних показників проводився на вибірці з 58 дітей. Для методики «Шкала оцінювання дитячого аутизму» встановлено, що показник від 15 до 30 балів свідчить про відсутність аутизму, від 30 до 37 балів - про легкий / помірний ступінь аутизму, від 37 до 60 балів - про важкий аутизм.

Отже, україномовні версії методик «Шкала оцінювання дитячого аутизму» та «Психолого-освітній профіль» 
характеризуються високими психометричними показниками (валідністю та надійністю), що дає підстави використовувати їх для діагностики дітей з аутизмом.

Реколендацї шодо вибору діагностичних летодик дослідження дітей із різнил ступенел аутизлу.

Нами проаналізовано діагностичні методики, які застосовуються для визначення психофізичних характеристик дітей із РСА. Застосування тієї чи іншої діагностичної методики вимагає досить тривалого часу дослідження, що не завжди легко здійснити у випадку з дітьми з РСА (наприклад, дитина може концентрувати увагу лише 10-15 хв, що свідчить про необхідність пролонгованого дослідження тривалістю до 3-4 днів). Натомість нормативні документи (наприклад, лист МОН України від 26.07.2012 № 1/9-529 «Про організацію психологічного і соціального супроводу в умовах інклюзивного навчання») визначають регламентовані рамки роботи з дитиною. Особливо це стосується Положення про ПМПК, на засіданні якої визначаються освітні можливості дитини (тривалість однієї консультації - до 40 хв). Тобто, необхідно оптимізувати процедуру діагностики, залучаючи при цьому всі наявні ресурси - державних і приватних надавачів послуг, у т. ч. ресурси громадських організацій.

Iз точки зору вибору діагностичних методик, серед існуючого спектра методик необхідно керуватися результатами проведеного аналізу, проілюстрованими на рис. 1.

Як бачимо з рис. 1 , залежно від ступеня аутизму можна рекомендувати такі методики:

- для легкого ступеня аутизлу - методика М-СНАТ i скринінгова діагностична методика SCQ, призначені для проведення скринінгу дітей віком 1,5-3 роки та визначення групи ризику захворювання аутистичного спектра;

- для полірного ступеня аутизлу - методики CARS, CASD, ADI-R - для визначення основних характеристик дітей із РCA; 
- для важкого ступеня аутизлу - методика ADOS-2 для встановлення медичного діагнозу, методика PEP-R для визначення психоосвітнього профілю дітей із РCA.

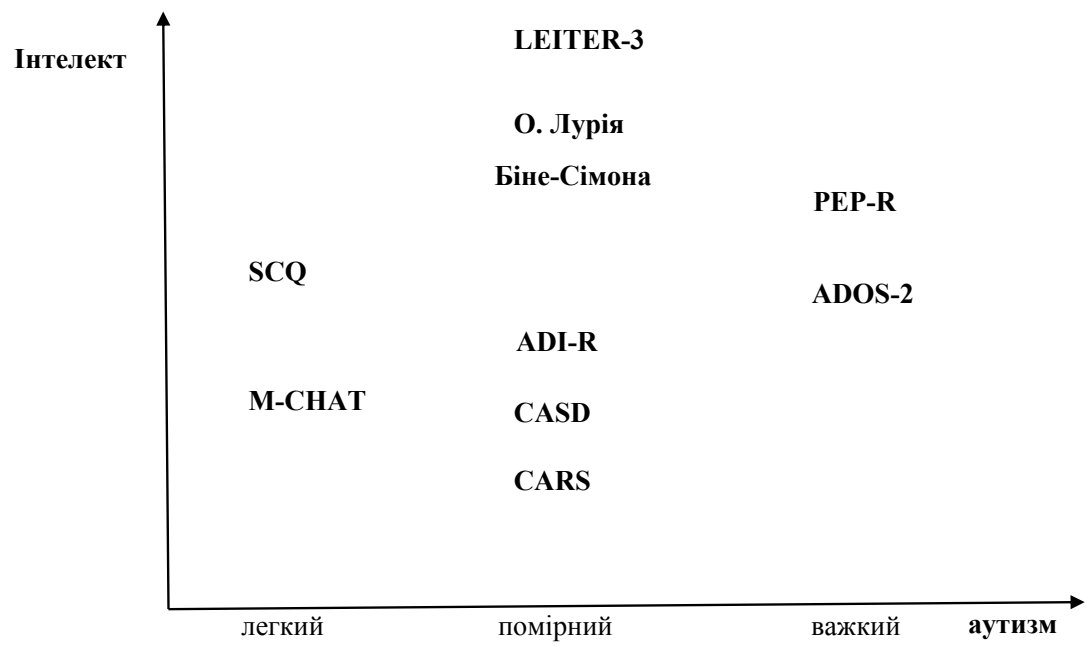

Рис. 1. Рекомендації щодо вибору діагностичних методик залежно від ступеня аутизму, рівня інтелектуального розвитку та наявності невербального мовлення у дітей із PCA

Із точки зору майбутньої корекції порушень розвитку дітей із РСА у спеціальній та інклюзивній школі, найефективнішою є методика PEP-R.

Разом із тим, серед дітей із РСА досить поширеним явищем є слабо виражене або відсутнє мовлення, що ускладнює діагностику та моніторинг за вищенаведеними методиками. У цьому випадку досить ефективною є методика LEITER-3 (тест невербального інтелекту та когнітивних здібностей) [Roid, 1997: 153].

Отже, методики вивчення розумового розвитку, LEITER-3 та нейропсихологічне дослідження можна ефективно застосовувати для визначення рівня розумового розвитку дітей із РСA. 
Щодо визначення рівня інтелектуального розвитку в немовних дітей із PCA передбачається можливість використання методики LEITER-3.

Методика LEITER-3 була розроблена Расселом Лейтером для вікової категорії від 2 до 18 років. Метою цієї методики є визначення коефіцієнта G (або загального інтелекту) шляхом аналізу зорово-рухової активності дитини. Застосування цієї методики не передбачає словесної інструкції.

Отже, методика LEITER-3 може вимірювати інтелект різних вікових, культурних і економічних груп, а також осіб із порушеннями мовлення, глухих дітей та інших дітей з особливими потребами. Ця методика містить 54 пункти, які розбиті на чотири категорії для кожного віку, починаючи від 2-х до 10-річного віку. Завдяки цьому кожен елемент відповідає психологічному віку дитини - 3 місяці. Крім того, є ще дві категорії для кожної вікової групи від 11 до 18 років, де кожен елемент відповідає психологічному віку дитини - 6 місяців.

Елементи випробувань упорядковані й організовані відповідно до ступеня їх складності. Хоча всі елементи Iрунтуються на продуктивності виконання завдань, проте вони мають різний зміст, включаючи виявлення подібних кольорів, сортування деталей, колір і відповідність форми, упорядкування кола, виявлення та розпізнавання міміки, таким чином виявляючи вікові відмінності, просторові відносини, ідентифікуючи подібні аспекти, ланцюжки i класифікації тварин відповідно до їх проживання. Елементи, призначені для дітей молодшого віку, - прості. Ця простота забезпечує можливість навчання для дитини і налагодження з нею хороших стосунків. Отже, вся методика побудована, як гра для дитини.

При підрахунку балів, що відповідають позитивному вирішенню дитиною проблемних ситуацій, обчислюється базовий вік дитини. Отримане число показує рівень інтелектуального розвитку дитини. 
Для визначення валідності діагностичної методики LEITER-3 проведемо порівняльний аналіз результатів, отриманих за методиками А. Біне - T. Сімона та LEITER-3. Для дослідження було обрано 56 дітей із дошкільних навчальних закладів і середньої школи (діти віком від 3 до 5 років - 18, діти віком від 6 до 16 років - 36).

Для перевірки відповідності методик використовували показник альфа-Кронбаха. Результати проведених досліджень представлено у табл. 3.

Таблиця 3. Результати співставлення методик LEITER-3 та методика визначення розумового розвитку за критерієм альфа Кронбаха

\begin{tabular}{|c|c|}
\hline Психологічний вік дітей & Показник альфа Кронбаха \\
\hline 2 роки 1 місяць -4 роки 5 місяців & 0,75 \\
\hline 4 роки 6 місяців -6 років 9 місяців & 0,83 \\
\hline
\end{tabular}

Отже, результати табл. 3 показали непогану збіжність результатів обстеження дітей із РСА за обома методиками, що вказує на валідність застосування методики LEITER-3 для діагностики аутичних дітей.

\section{Висновки}

На основі проведених досліджень 56 дітей із розладами спектра аутизму (діти віком від 3 до 5 років - 18, діти віком від 6 до 16 років - 38) м. Львова, м. Полтави, м. Києва та м. Кривого Рогу отримані такі результати:

1. Визначено комплекс діагностичних методик, які дають змогу оптимізувати діагностику дітей із PCA: M-CHAT, скринінгова діагностична методика SCQ - для проведення скринінгу дітей віком 1,5-3 роки та визначення групи ризику захворювання аутистичного спектра; методики CARS, CASD, ADI-R - для визначення основних характеристик дітей із PCA; методики Біне - Сімона, LEITER-3, О.Р. Лурія - для визначення рівня розумового розвитку; 
методика PEP-R - для визначення психоосвітнього профілю дітей із РСА.

2. Проведено порівняльний аналіз зарубіжних і вітчизняних діагностичних методик для здійснення психолого-педагогічної діагностики дітей із PCA; зокрема, перевірено критерії валідності методик LEITER-3 та Біне - Ciмона для визначення рівня інтелекту в аутичних дітей.

\section{Література}

Островська К.О. Засади комплексної психолого-педагогічної допомоги дітям з аутизмом. Львів : «Тріада плюс», 2012. 520 с.

Островська К.О., Рибак Ю.В, Мельник У.Р. Соціальний супровід дітей з аутизмом під час навчання. Львів : «Тріада плюс», 2009. 188 с.

Сайко Х.Я. Психологічні особливості педагогів з різним рівнем ставлення до залучення аутичних дітей в загальноосвітні школи. Корекиійна педагогіка та спеціальна психологія. 2013. Вип. 23. C. 395-399.

Скрипник Т.В. Стандарти психолого-педагогічної допомоги дітям з розладами аутичного спектра. Київ : Знання, 2013. 60 с.

Шульженко Д.І. Основи психологічної корекції аутичних порушень у дітей. Київ : Знання, 2009. 386 с.

Cohen, S., Bleiweiss, J., Mouzakitis, A., \& Fahim, D. (2012). Strategies for Supporting the Inclusion of Young Students With Autism Spectrum Disorders. Focus on Inclusive Education, 8 (1), 1-7.

Eldar, E., Talmor, R, \& Wolf-Zukerman, T. (2010). Successes and difficulties in the individual inclusion of children with Autism Spectrum Disorder (ASD) in the eyes of their coordinators. International Journal of Inclusive Education, 14 (1), 97-114.

Filipek, P.A., \& Baranek, G.T. (2000). The screening and diagnosis of autistic spectrum disorders. Journal of Autism and Developmental Disorders, 30, 439-484.

Gavalda, J.M., Qinyi, T. (2012). Improving the process of inclusive education in children with ASD in mainstream schools. Procedia. Social and Behavioral Sciences, 46, 4072-4076.

Lindsay, S., Proulx, M., Thomson, M., \& Scott, H. (2013). Educators' Challenges of Including Children with Autism Spectrum Disorder in Mainstream Classrooms. International Journal of Disability, Development and Education, 60 (4), 347-362.

Martsenkovsky, I., Bikshaieva, Ia., Vashenko, O., \& Kazakova, S. (2011). Efficacy of special early behavioral intervention (SEBI) in toddlers with autism spectrum disorders (ASD)]. European Child \& Adolescent Psychiatry, 20, 145. 
Ostrovska, K.O. (2013). Peculiarities of social competence in children with different autistic levels]. Journal of Education, Culture and Society, $1,133-147$.

Roid, G.H., \& Miller, L.J. (1997). Leiter International Performance ScaleRevised. Examiners Manual Wood Dale, IL: Stoeling Co.

\section{References}

Ostrovska, K.O. (2012). Zasady kompleksnoi psykholoho-pedahohichnoi dopomohy ditiam z autyzmom [Fundamentals of comprehensive psychological and pedagogical assistance to children with autism ]. Lviv : «Triada plius» [in Ukrainian].

Ostrovska, K.O., Rybak, Yu.V, \& Melnyk, U.R. (2009). Sotsialnyi suprovid ditei z autyzmom pid chas navchannia [Social support for children with autism during study]. Lviv : «Triada plius» [in Ukrainian].

Sajko, H.Y. (2013). Psyhologichni osoblyvosti pedahohiv z riznym rivnem stavlennia do zaluchennia autychnykh ditei v zahalnoosvitni shkoly [Psychological Peculiarities of Teachers with Different Levels of Attitude to Attracting Autistic Children to Comprehensive Schools]. Korektsiina pedahohika ta spetsialna psykholohiia, 23, 395-399 [in Ukrainian].

Skrypnyk, T.V. (2013). Standarty psykholoho-pedahohichnoi dopomohy ditiam z rozladamy autychnoho spektra [Standards of psychological and pedagogical assistance to children with autism spectrum disorders ]. Kyiv : Znannia [in Ukrainian].

Shulzhenko, D.I. (2009). Osnovy psykholohichnoi korektsii autychnykh porushen $u$ ditei [Fundamentals of psychological correction of autistic disorders in children ]. Kyiv : Znannia [in Ukrainian].

Cohen, S., Bleiweiss, J., Mouzakitis, A., \& Fahim, D. (2012). Strategies for Supporting the Inclusion of Young Students With Autism Spectrum Disorders. Focus on Inclusive Education, 8 (1), 1-7.

Eldar, E., Talmor, R, \& Wolf-Zukerman, T. (2010). Successes and difficulties in the individual inclusion of children with Autism Spectrum Disorder (ASD) in the eyes of their coordinators. International Journal of Inclusive Education, 14 (1), 97-114.

Filipek, P.A., \& Baranek, G.T. (2000). The screening and diagnosis of autistic spectrum disorders. Journal of Autism and Developmental Disorders, 30, 439-484.

Gavalda, J.M., Qinyi, T. (2012). Improving the process of inclusive education in children with ASD in mainstream schools. Procedia. Social and Behavioral Sciences, 46, 4072-4076.

Lindsay, S., Proulx, M., Thomson, M., \& Scott, H. (2013). Educators' Challenges of Including Children with Autism Spectrum Disorder in Mainstream Classrooms. International Journal of Disability, Development and Education, 60 (4), 347-362. 
Martsenkovsky, I., Bikshaieva, Ia., Vashenko, O., \& Kazakova, S. (2011). Efficacy of special early behavioral intervention (SEBI) in toddlers with autism spectrum disorders (ASD)]. European Child \& Adolescent Psychiatry, 20, 145.

Ostrovska, K.O. (2013). Peculiarities of social competence in children with different autistic levels]. Journal of Education, Culture and Society, $1,133-147$.

Roid, G.H., \& Miller, L.J. (1997). Leiter International Performance ScaleRevised. Examiners Manual Wood Dale, IL: Stoeling Co.

\section{АНОТАЦІЯ}

у статті проведено апробацію комплексу психодіагностичних методик для визначення ступеня аутизму та соціальних компетентностей дітей зі спектром аутистичних порушень (РСА). Загальна кількість dimeй із РСА, які склали вибірку для адаптації методик, становила 56 осіб, серед яких 18 дітей віком від 3 до 5 років і 38 дітей віком від 6 до 16 років. Для аналізу кількісних результатів дослідження застосовано математично-статистичні методи обробки з використанням програмного пакету STATISTICA-8.0: порівняльний аналіз за t-критерієм Стьюдента, кластерний, дискримінантний і кореляційний аналізи. На основі проведеного кореляційного та дискримінантного аналізу визначено діагностичні методики, які доцільно використовувати для первинної та поглибленої діагностики дітей як підгрунтя розроблення навчальних і розвивальних програм в інклюзивному просторі. Залежно від ступеня аутизму можна рекомендувати такі методики: для легкого ступеня аутизму - методика М-СНАТ і скринінгова діагностична методика SCQ, призначені для проведення скринінгу дітей віком 1,5-3 роки та визначення групи ризику захворювання аутистичного спектра; для помірного ступеня аутизму - методики CARS, CASD, ADI-R - для визначення основних характеристик дітей із PCA; для важкого ступеня аутизму - методика ADOS-2 для встановлення медичного діагнозу, методика PEP-R - для визначення психоосвітнього профрілю diтей із PCA. Для diтей із PCA зі слабо вираженим або відсутнім мовленням перевірено можливість використання тесту невербального інтелекту та когнітивних здібностей LEITER-3. Визначено валідність діагностичної методики LEITER-3, проведено порівняльний аналіз результатів, отриманих за методикою LEITER-3. Для перевірки відповідності методик використовували критерій альфа Кронбаха. Установлено, шо методики LEITER-3 та нейропсихологічне дослідження за О. Лурія можна ефективно застосовувати для визначення рівня розумового розвитку dimeй із 
РСА. Діагностичні методики покладені в основу створення профілю розвитку дитини, надання рекомендацій щодо подальшої корекційної роботи і визначення освітньо-реабілітаційного маршруту дитини.

Виявлено комплекс діагностичних методик, які дають змогу оптимізувати діагностику дітей із РСА: М-CHAT, скринінгова діагностична методика SCQ - для проведення скринінгу дітей віком 1,5-3 роки та визначення групи ризику захворювання аутистичного спектра; методики CARS, CASD, ADI-R - для визначення основних характеристик дітей із PCA; методики LEITER-3, O.P. Лурія - для визначення рівня розумового розвитку; методика PEP-R - для визначення психоосвітнього профілю dimeŭ із PCA.

Проведено порівняльний аналіз зарубіжних і вітчизняних діагностичних методик для здійснення психолого-педагогічної діагностики дітей із PCA; зокрема, перевірено критерії валідності методики LEITER-3 та Біне - Сімона для визначення рівня інтелекту в аутичних dimeй.

Ключові слова: діагностика, компетентності, діти, розлади спектра аутизму, інклюзивна освіта.

\section{Островская Катерина, Островский Игорь, Лобода Виктория. Основы психолого-педагогической диагностики детей с расстройствами спектра аутизма}

\section{АННОТАЦИЯ}

В статье проведена апробация комплекса психодиагностических методик для определения степени аутизма и социальных компетенций детей со спектром аутистических нарушений (РСА). Общее количество детей с РСА, составивших выборку для адаптации методик, составляло 56 человек, среди которых 18 детей в возрасте от 3 до 5 лет и 38 детей в возрасте от 6 до 16 лет. Для анализа количественных результатов исследования применены математически-статистические методы обработки с использованием программного пакета STATISTICA-8.0: сравнительный анализ по т-критерию Стьюдента, кластерный, дискриминантный и корреляционный анализы. На основе проведенного корреляционного и дискриминантного анализа определены диагностические методики, которые целесообразно использовать для первичной и углубленной диагностики детей как основание разработки учебных и развивающих программ в инклюзивном пространстве. В зависимости от степени аутизма можно рекомендовать следующие методики: для легкой степени аутизма - методика М-Chat и скринин- 
говая диагностическая методика SCQ, предназначенные для проведения скрининга детей 1,5-3 лет и определения группы риска заболевания аутистического спектра; для средней степени аутизма - методики Cars, CASD, ADI-R - для определения основных характеристик детей c PCA; для тяжелой степени аутизма - методика ADOS-2 для определения медицинского диагноза, методика PEP- $R$ - для определения психообразовательного профиля детей с РСА. Для детей с РСА со слабо выраженной или отсутствующей речью проверено возможность использования теста невербального интеллекта и когнитивных способностей LEITER-3. Определена валидность диагностической методики LEITER-3, проведен сравнительный анализ результатов, полученных по методикам LEITER-3. Для проверки соответствия методик использовали критерий альфа Кронбаха. Установлено, что методики LEITER-3 и нейропсихологическое исследование по А. Лурия можно эффрективно применять для определения уровня умственного развития детей с PCA. Диагностические методики положены в основу создания профиля развития ребенка, предоставления рекомендаций по дальнейшей коррекционной работе и определения образовательно-реабилитационного маршиута ребенка.

Выявлен комплекс диагностических методик, которые позволяют оптимизировать диагностику детей с PCA: M-Chat, скрининговая диагностическая методика SCQ - для проведения скрининга детей 1,5-3 лет и определения группы риска заболевания аутистического спектра; методики Cars, CASD, ADI-R-для определения основных характеристик детей с PCA; методики LEITER-3, O.P. Лурия - для определения уровня умственного развития; методика $P E P-R$ - для определения психообразовательного профиля детей с РСА.

Проведен сравнительный анализ зарубежных и отечественных диагностических методик для осуществления психолого-педагогической диагностики детей с PCA; в частности, проверено критерии валидности методики LEITER-3 и Бине - Симона для определения уровня интеллекта у аутичных детей.

Ключевые слова: диагностика, компетентности, дети, расстройства спектра аутизма, инклюзивное образование. 